\title{
TRAKTAT O ZŁYCH I ŁAGODNYCH TYRANACH
}

Timothy Snyder, O tyranii. Dwadzieścia lekcji z dwudziestego wieku, przekład Bartłomiej Pietrzyk, Kraków: Znak Horyzont 2017, ss.127

Opublikowana w formie małego katechizmu rozprawka prof. Timothy Snydera z Uniwersytetu Yale przeszła jakby niedostrzeżona, może uznana za katechizm wolności, a wiadomo, że nad taką publikacją nie ma debaty. A przecież sam autor, wybitny znawca historii Europy środkowowschodniej, a szczególnie losów Rzeczypospolitej szlacheckiej, napisał w tymże katechizmie, że „sięganie do historii jest jedną z podstawowych tradycji Zachodu" (s.10). Model zachodniej liberalnej, pluralistycznej demokracji jest ideałem autora, co więcej - najlepszym porządkiem gwarantującym pełnię praw obywatelskich. Bo cały traktat prof. T. Snydera jest jednym wielkim protestem przeciw rządom arbitralnym, despotycznym, które uosabia w przeszłości istnieniem, co prawda krótkim, anegdotycznych tyranii. Dla prof. Syndera tyrania jest wynikiem całkowitej bierności i apatii społeczeństwa. Autor pisze wyraźnie, że jego traktat adresowany jest do społeczności ludzi młodych, głównie w USA, ale rozszedł się wszak także w Europie. Tylko europejska historiografia nieco głębiej spogląda w historię, niż wzmiankowani przez autora filozofowie, co zwięźle nazywali tyranią - uzurpowanie władzy przez jednostkę, wnikliwiej, niż zademonstrował to swoim czytelnikom prof. Timothy Snyder.

Wybitny historyk niemiecki Theodor Mommsen (1817-1903), laureat Nagrody Nobla za rok 1902, stale pozostający w konflikcie z kanclerzem Bismarckiem, napisał: „Historia to odprawianie sądów nad zmarłymi pokoleniami przez żyjących”. Według prof. Snydera dawni filozofowie uznawali za tyranię fakt zagarnięcia całej władzy przez jednostkę lub określoną grupkę ludzi (s. 10). Już samo pojęcie „tyrana" budziło zrozumiałe obrzydzenie. Ale historia antyku jest dość skomplikowana i może czytelnik zapytać autora tego „katechizmu wolności”: a co z łagodnymi tyranami? Wsadzimy ich do jednego piekielnego pieca z tymi złymi tyranami XX wieku? Wszak tyran Dionizjos I (430-367) z Syrakuz na Sycylii okazał się

1 A.F. Grabski, Dzieje historiografii, Poznań: Wydawnictwo Poznańskie 2011, s. 497-498. 
bardzo inteligentnym, wykształconym, piszącym artystyczne utwory. Zapraszał do siebie na debaty Platona, który przybył do Syrakuz i który dyskutował długie wieczory z tyranem. Platon przekonywał długo do swego modelu państwa rządzonego przez filozofów, w końcu rozczarowany brakiem kompromisu - opuścił Syrakuzy. Dionizjos zaś rozważał zaprezentowany mu model państwa Platona, gdzie miała być klasa wojowników, klasa kupców oraz rzemieślników i co najdziwniejsze nawet wspólne żony...? Nie wiemy dokładanie, co poróżniło tyrana z Platonem, ale filozof swobodnie odpłynął do Aten. Platon pokazał się powtórnie w Syrakuzach, gdy rządził tam już syn poprzedniego, Dionizjos II (367-345). Debaty z nim zakończyły się ostatecznie powrotem ponownym Platona do Aten, ale tyran Dionizjos II zrezygnował z modelu rządów tyrańskich, mimo tego, że jego doradcą był uczeń Platona - niejaki filozof Dion. Tyran stał się zwykłym obywatelem Syrakuz i żył tam swobodnie i długo jako zwykły mieszkaniec. Nikt nie próbował pozbawić go głowy. Władza absolutna jednostki znana była też w antycznym Rzymie, gdy bowiem powołano Cyncynata, 80-letniego starca, na dyktatora w chwili zagrożenia Rzymu, ten dyktator bez żadnego wahania rozkazał uciąć głowę sprzeciwiającemu się mu bogatemu ekwicie Spuriuszowi Meliuszowi. Dziwne, ale historycy nie obciążają tyrana Dionizjusza obcinaniem głów swoim oponentom. Cycero komentując rolę męża stojącego na czele władzy pisze, że nie mogą oni w żadnym wypadku kierować się gniewem, lecz wyłącznie sprawiedliwością².

Nie wiem, jak autor, zagorzały obrońca demokracji pluralistycznej i wolności obywatelskich, przeoczył w swoim ognistym „katechizmie wolności”, adresowanym wszak głównie do czytelnika amerykańskiego, nazwisko Thomasa Paine'a (17371809 ). Ten wybitny obrońca praw człowieka i obywatela jest autorem dzieła The Rights of Man (1791-1792). Broszura ukazała się w nakładzie 50 tys. egzemplarzy! Ten incydent zaniepokoił nawet władze parlamentarnej wszak monarchii Jerzego V. Autora odwiedziło kilku „smutnych panów w kapeluszach” z policji politycznej premiera Williama Pitta młodszego. W obawie przed oskarżeniem, że „podważa chlubne tradycje rewolucji 1688 roku", autor schronił się w rewolucyjnym Paryżu, u markiza Antoine de Condorceta (1743-1794). Paine miał swoistego pecha, bo publicznie sprzeciwiał się wyrokowi śmierci na Ludwika XVI w traktacie Opinion de Thomas Paine sur l'Affaire de Louis Capet. Nazwisko Paine'a, aresztowanego przez jakobinów, widniało już na liście osób skazanych na gilotynę, ale szczęśliwie obalenie rządów Robespierre'a przywróciło mu wolność i prestiż. Po obaleniu Dyrektoriatu przyjął go na audiencji sam pierwszy konsul Napoleon Bonaparte

2 Marek Tuliusz Cycero, Wybór pism naukowych, oprac. M. Plezia, Wrocław: Ossolineum 1954, s. 126-127. 
i w bardzo przyjaznej rozmowie zapewnił autora, że jego traktat Les Droits de l'Homme „trzyma jako ulubioną lekturę pod poduszką"3. Ten były więzień jakobinów, choć popierał generalnie Rewolucję Francuską, ale nigdy jej odłamu jakobińskiego, skrajnie antyreligijnego i burzycielskiego, dał temu wyraz w broszurce $L e$ Siècle de la Raison ou le Sens Commun des Droits de l'Homme i bardzo rychło opuścił Francję, udając się przez Anglię do Stanów Zjednoczonych. Historycy twierdzą, że Paine przeniósł spór o prawa obywatela i demokrację z grona filozofów do olbrzymich mas ${ }^{4}$. Autor recenzowanej pracy przywołał jednak filozofa Arystotelesa (s. 9), który nie tylko potępiał tyranię, ale i ostrzegał obywateli Aten, by w żadnym wypadku nie dopuszczali do długotrwałego piastowania głównych urzędów przez jedną osobę, bo właśnie „długi okres urzędowania w oligarchiach oraz w demokracjach stawa się podstawą do wytworzenia tyranii"'. Jednak ten temat uchodzi dziś uwadze tysiącom głosujących obywateli z tej prostej racji, że nigdy nie słyszeli o wykładzie zasady rządów Arystotelesa.

Naturalnie autor, wyborny znawca losów Europy powersalskiej, trafnie konstatuje, że Hitler po zwycięstwie wyborczym w 1933 r., szybko i skutecznie przekształcał Niemcy w państwo monopartyjne. Wykorzystał skutecznie kryzys i niepopularność „systemu powersalskiego", a jego skryte marzenia o rewanżu i powrocie do mapy Europy z 1914 r., z całkowitym zignorowaniem dwunastu nowych państw, powstałych w rezultacie traktatu wersalskiego, głównie z ambitnej inicjatywy prezydenta Woodrowa Wilsona, znalazły poparcie licznych finansowych elit w Niemczech weimarskich.

Autor kreśli następnie fatalny skutek sukcesów Hitlera, jakim okazało się błyskawiczne przyłączenie Austrii do Niemiec, bez jednego wystrzału. Skutkowało to tym, że Anschluss stał się nie tylko już upokorzeniem społeczności żydowskiej, ale także ułatwił rabunek jej własności czy nawet stworzył okazję do publicznego policzkowania Żydów (s. 35 i 45). Społeczność żydowska, mimo całej spolegliwości, zaledwie była tolerowana, z coraz uboższym zakresem praw obywatelskich. Natomiast większość znakomita obywateli Austrii zastosowała antyczną maksymę Cycerona: Ex malio eligere minima...(wybierz mniejsze zło).

Katechizm wolności pióra prof. T. Snydera, adresowany wszak głównie do młodzieży amerykańskiej, tworzy bardzo spłaszczony, a przeto fałszywy obraz Europy, na przekór rzeczywistym humanitarnym i wolnościowym intencjom autora. W tym samym czasie żyłem i przygotowywałem się do pójścia do drugiej klasy szkoły

3 Ch. Hitchens, Thomas Paine. Prawa człowieka. Biografia, Warszawa: Wydawnictwo Literackie Muza SA 2008, s. 70.

4 Tamże, s. 105-106.

5 Arystoteles, Polityka, Warszawa: PWN 2006, s. 226 i 257. 
podstawowej w uroczej Florencji Pótnocy, czasem nazywanej Paryżem Pótnocy, czyli w Wilnie, w Drugiej Rzeczypospolitej. W mieście ponad 200-tysięcznym, gdzie mniejszość żydowska liczyła 29\% mieszkańców, natomiast Polacy 69\% ludności. Zdarzały się bardzo nieliczne zamieszki młodzieży w 1938 r., incydent zakończony śmiercią polskiego studenta. Sprawca tego zabójstwa, Żyd Samuel Wofin, skazany został prawomocnym wyrokiem na dwa lata więzienia. Mniejszość żydowska bardzo skutecznie broniła się przed grupkami nielicznej młodzieży endeckiej w Wilnie. Wilno od 1920 r. było tradycyjnie ziemia pitsudczyków, nie doszło też do utworzenia na Uniwersytecie Wileńskim getta ławkowego; zbyt żywe były liberalne tradycje polityki księcia Adama Jerzego Czartoryskiego z początków XIX wieku, który dopuścił aż 40 Żydów do studiowania oraz do wykładania na tejże Uczelni ${ }^{6}$. A zatem jeszcze w sierpniu 1939 r. spacerowałem z moją Mamą po ulicy Niemieckiej oraz okolicznych ulicach, bo tam taniej wszystkie przybory szkolne i ubrania można było zakupić w sklepie żydowskim (po przetargu) i takie zakupy nie były w Wilnie żadną herezją. Mniejszość żydowska do 17 września 1939 r. cieszyła się, nie tylko zresztą w Wilnie, pełnią praw obywatelskich. Nie zachodzi tutaj żadna jedność położenia mniejszości żydowskiej w Niemczech od 1933 r. lub Austrii 1938 z sytuacją tejże mniejszości w Polsce powersalskiej.

Nie mogę także podpisać się pod zdaniem autora tej publikacji, że „w latach 20-tych i 30-tych XX wieku demokracje europejskie stoczyły się w otchłań prawicowego autorytaryzmu i faszyzmu" (s. 11). Całkiem inaczej było w Wilnie lub Warszawie, a zupełnie inaczej w Kownie, Bukareszcie, Budapeszcie, Rydze lub Sofii. Dziwi mnie bardzo, że autor używa terminów faszyzm (s. 11) lub nazizm (s. 18) bez wythumaczenia tych terminów, bo przecież nie są to terminy identyczne ${ }^{7}$. Chyba nikt inny jak historyk II wojny światowej nie może być bardziej wyczulony na używanie tych terminów. Nazwa partii NSDAP też wymaga wyjaśnienia, tym bardziej jeśli autor używał już - jak wspomniałem - terminu naziści (s. 29). Mordy na społeczności żydowskiej autor trafnie opisuje idąc śladem wspomnień Teresy Prekerowej, historyczki Holokaustu (s. 56-57). Autor też bez cienia wątpliwości piętnuje wielką skalę morderstw popełnionych na Żydach na rubieżach Europy Wschodniej przez tzw. Einsatzgruppen, gdzie nie tylko „dowódcy ale i w zasadzie wszyscy ich podwładni, a były ich tysiące - byli mordercami” (s. 49). Tylko jak historyk ma się ustrzec przed nadmierną generalizacją własnych opinii?

W końcu lipca 1944 r. znalazłem się z woli mojej Mamy w gospodarstwie rolnym jej brata, położonym $30 \mathrm{~km}$ od Wilna, które przez Armię Czerwoną było już

6 W. ZAJewski, Czy historycy piszą prawdę, Kraków: Arcana Historii 2015, s. 305.

7 Zob. Mały oksfordzki stownik historii świata w XX wieku, Warszawa: Świat Książki 1995, s. 165; R. SCruton, Stownik myśli politycznej, Poznań: Zysk i S-ka 2002, s. 230. 
opanowane, ponieważ wśród mieszkańców miasta panował lęk przed odwetowym nalotem niemieckim. Ten oczekiwany nalot stał się faktem, bomby bardziej spadły na ulicę Śniegową oraz inne pobliskie ulice niż na kolej. Zginęło wielu moich sąsiadów. Zanosząc śniadanie dla pastuszka, nieoczekiwanie napotkałem go przerażonego, otoczonego przez trzech uzbrojonych, młodych żołnierzy Wehrmachtu!!! Była to zagubiona, przerażona grupka chłopców o jakieś 5 lub 6 lat tylko starszych ode mnie. Nie mieli oni żadnych szans na złożenie broni i kapitulację, bo takie zagubione, rozproszone grupki były zwyczajnie $\mathrm{z}$ chwilą ich schwytania rozstrzeliwane. Linia frontu znajdowała się jakieś 150 lub $200 \mathrm{~km}$ dalej, szanse na przebicie się do swoich były bliskie zeru. Nie było w ich oczach ani w ich słowach uwielbienia dla Hitlera, ale ogromna chęć życia i chyba przytulenia się do matki ${ }^{8}$. Tak to już bywa, pisał Alexander Demandt, że przy rekonstrukcji faktów historycznych niezbędna jest także odrobina wyobraźni, bo pewność jest dla historyka nieosiągalna9.

Cenię autora, że zgodnie ze stanem rzeczywistym napisał otwarcie: „w lecie 1939 roku Związek Radziecki sprzymierzył się z nazistami, a Armia Czerwona przyłączyła się do Wehrmachtu dokonując inwazji na Polskę" (s. 53). Niestety, autor nigdzie w tekście nie wspomniał o pakcie Ribbentrop-Mołotow z 23 sierpnia 1939 r., ani też o jego uzupełnieniach, o przyjaznym sąsiedztwie i granicach z 28 września 1939 r. ${ }^{10}$

Plusem znaczącym dla autora jest przyznanie, że ustrój bolszewicki nie przyniósł oczekiwanej demokratyzacji, przeciwnie, gwałtowna industrializacja oraz kolektywizacja spowodowały, iż „w latach 1930-1933 miliony ludzi na sowieckiej Ukrainie, w Kazachstanie oraz w Rosji zginęły straszną, upokarzającą śmiercią" (s. 34-35 i 48). Skoro prof. Timothy Snyder pisze o okrutnej śmierci głodowej, to zgodnie z realnymi faktami trzeba podać, że to już w 1921 r. cała radziecka gospodarka legła w gruzach, a miliony chłopów znalazło się w wyniku przymusowej rekwizycji zboża oraz kolektywizacji już w 1921 r. na pograniczu śmierci głodowej i sam Lenin powiedział, że ,powstania chłopów są o wiele niebezpieczniejsze niż wszyscy biali razem wzięci" 11 .

A skoro na str. 53 pojawia się wreszcie zdanie, że w 1939 r. ,,rząd Polski zdecydował się walczyć”, a w przedmowie do czytelnika polskiego (s. 8) autor pisze, że ,warto czerpać naukę z historii”, to zapytajmy go, skąd ta Polska znalazła się ponownie na mapie Europy i komu to zawdzięczała?

\footnotetext{
${ }^{8}$ W. Zajewski, Chłopiec z Wilna, Pruszcz Gdański: Wydawnictwo Agni 2011, s. 37 (wiersz: Trzech Żolnierzy).

9 A. Demandt, Historia niebyła, Warszawa: PIW 1999, s. 76-77.

${ }^{10}$ H. DyląGowa, Historia Polski 1795-1990, Lublin: Instytut Europy Środkowo-Wschodniej 2000, s. $167-169$.

${ }^{11}$ O. Figes, Szepty. Życie w stalinowskiej Rosji, Warszawa: Wydawnictwo Magnum 2010, s. 5.
} 
Budzi moje ogromne zdziwienie nieobecność w tekście nazwiska prezydenta Woodrowa Wilsona (1856-1924), rektora Princeton University, jednego z głównych architektów traktatu wersalskiego i tej niedoskonałej, skomplikowanej terytorialnie Europy powersalskiej, z licznymi nowymi państwami narodowymi. To przecież ten prezydent oświadczył 22 stycznia 1917 r. w senacie, iż „every people has a right to choose the sovereignity under which they shall live”"12. Teza Wilsona, że „rządy czerpią swą władzę ze zgody i woli rządzonych i nigdzie nie ma takiego prawa, na mocy którego wolno byłoby przerzucać narody spod jednego panowania pod drugie, tak jakby były prywatną własnością" i inne jego tezy były całkowitym zakwestionowaniem i podważeniem traktatu wiedeńskiego z 1815 r. i ustalonej tam na 103 lata mapy Europy ${ }^{13}$.

Nie wdając się w tym miejscu w debatę o traktacie wersalskim, można jednak zadać pytanie: Czy prezydent Wilson był świadom zagrożenia cywilizacyjnego, jakie niosła ze sobą rewolucja bolszewicka? Nurtowały go może obawy, czy w Moskwie nie rządzi przypadkiem sekta terrorystów? Wilson świadom był wszakże tej możliwości, iż siły amerykańskie już zgromadzone w Europie, wspólnie z armią angielską zdolne są powstrzymać rewolucję bolszewicką i przechylić szalę zwycięstwa na stronę białych ${ }^{14}$. Prezydent Wilson, zdając sobie sprawę z dużego jednak ryzyka przedłużenia konfliktu zbrojnego w Europie, widząc ogromne wyczerpanie Ententy i narastający ferment w samej Ameryce, zdecydował się wysłać w lutym 1919 r. specjalną misję do Moskwy. Jej przedstawiciele mieli bezpośrednio z Leninem ustalić, czy możliwe jest zażegnanie zbrojnego konfliktu, ale pod pewnymi jednak warunkami. Na czele tej misji stanął podpowiedziany przez płk. Edwarda M. House'a i desygnowany przez prezydenta Wilsona - William C. Bullitt (18911967), który od 1914 r. był doradcą rządu amerykańskiego do spraw rosyjskich. Bullittowi mieli towarzyszyć nadto Lincoln Steffens oraz lewicowy dziennikarz szwedzki Karl Klibom. W bezpośrednich, trzytygodniowych rokowaniach w lutym 1919 r., Lenin zapewnił delegację amerykańską, że rewolucja bolszewicka 1917 r. przekształciła Rosję w kraj całkowicie demokratyczny, niemający już nic wspólnego z autorytaryzmem i carskim despotyzmem. W tej więc sytuacji autorzy raportu stwierdzali: „Amercican troops were doing no sort of good in Russia”15, zaś co dotyczy zobowiązań dłużniczych Rosji wobec USA oraz innych krajów Ententy, to

\footnotetext{
${ }^{12}$ N. Ferguson, Colossus. The Price of America's Empire, New York: Peguin Press 2004, s. 63.

${ }^{13}$ J. Duroselle, Wielka wojna Francuzów 1914-1918, Warszawa: Bellona 2006, s. 387; W. ZAJewski, Sprawa polska na kongresie wiedeńskim, „, Czasy Nowożytne”, 21(2008), s. 43-44; Historia dyplomacji polskiej X-XX w., red. G. Labuda i W. Michowicz, Warszawa:Wydawnictwo Sejmowe 2002, s. 455 (wykład prof. Piotra Łossowskiego).

${ }^{14}$ N. Ferguson, Colossus, s. 64-65.

${ }^{15}$ Tamże, s. 65.
} 
owe długi będą stopniowo i systematycznie regulowane. Wszystkie niepokoje Waszyngtonu są więc nieuzasadnione, bo w istocie nie ma żadnego konfliktu między USA a nowo budowanym, demokratycznym państwem rosyjskim. Tak więc mocno lewicowa delegacja amerykańska przedłożyła raport prezydentowi Wilsonowi, że nie widzi żadnych powodów do zbrojnej interwencji w Rosji, skoro ta, jako państwo całkowicie zdemokratyzowane uznaje wszystkie swoje długi wobec Ameryki ${ }^{16}$. Na spotkaniu w Paryżu, w trakcie zawiłych prac na kongresie wersalskim, prezydent Woodrow Wilson i premier Wielkiej Brytanii David Lloyd George (1863-1945) osiągnęli porozumienie, że żadnej interwencji zbrojnej obu tych mocarstw na rzecz zwycięstwa „strony białych” w rewolucji domowej w Rosji nie będzie. Prezydent Wilson pozostał w przekonaniu, że skutecznie przyczynił się do upadku trzech imperiów: Hohenzollernów, Habsburgów oraz Imperium Ottomańskiego ${ }^{17}$.

\section{BIBLIOGRAFIA}

Arystoteles, Polityka, Warszawa: PWN 2006.

CyCero Marek Tuliusz, Wybór pism naukowych, oprac. M. Plezia, Wrocław: Ossolineum 1954.

Demandt A., Historia niebyła, Warszawa: PIW 1999.

Duroselle J., Wielka wojna Francuzów 1914-1918, Warszawa: Bellona 2006.

DyląGowa H., Historia Polski 1795-1990, Lublin: Instytut Europy Środkowo-Wschodniej 2000.

Ferguson N., Colossus. The Price of America's Empire, New York: Peguin Press 2004.

Figes O., Szepty. Życie w stalinowskiej Rosji, Warszawa: Wydawnictwo Magnum 2010.

Grabski A.F., Dzieje historiografii, Poznań: Wydawnictwo Poznańskie 2011.

Historia dyplomacji polskiej X-XX w., red. G. Labuda i W. Michowicz, Warszawa:Wydawnictwo

Sejmowe 2002.

Hitchens Ch., Thomas Paine. Prawa człowieka, Warszawa:Wydawnictwo Literackie Muza SA 2008. Maty oksfordzki stownik historii świata w XX wieku, Warszawa: Świat Książki 1995.

SCruton R., Stownik myśli politycznej, Poznań: Zysk i S-ka 2002.

SNYDER T., O tyranii. Dwadzieścia lekcji z dwudziestego wieku, przekład B. Pietrzyk, Kraków: Znak Horyzont 2017.

ZAJewski W., Czy historycy pisza prawdę, Kraków: Arcana Historii 2015.

Zajewski W., Chłopiec z Wilna, Pruszcz Gdański: Wydawnictwo Agni 2011.

ZAJEwski W., Sprawa polska na kongresie wiedeńskim, „Czasy Nowożytne”, 21(2008), s. 33-45.

Władystaw Zajewski

em. prof. Instytutu Historii PAN

\footnotetext{
16 Tamże.

${ }^{17}$ Tamże, s. 172.
} 